\title{
Museum Culture of Remembrance:
}

\section{The Depiction of World War II in Japanese,}

\section{German and Austrian Museums}

\author{
Marco Sostero
}

\begin{abstract}
As one component of cultural memory, museums have the potential to co-form the remembrance of an entire society. They try to minimise the experience deficiency of their visitors and help them further to know and understand history in an interesting and vivid way. The present paper will show how and to what extent important museums in Japan, Germany and Austria try to shape the historical consciousness of their visitors. With the Yüshūkan in Tōkyō, the Heiwa Kinen Shiryōkan in Hiroshima, the Deutsches Historisches Museum in Berlin and the Heeresgeschichtliches Museum in Vienna, four representative institutions will be taken as indicators of the national efforts to re-appraise the history of World War II. Analyses of the different exhibitions, together with an international comparison, will document the individual position of each museum as well as its political intention. In addition, legal and cultural backgrounds that can lead to a country-specific, ideologically biased museum-based depiction of World War II will also be taken into consideration.
\end{abstract}

Keywords: World War II, Axis powers, culture of remembrance, museums II in Japanese, German and Austrian Museums." In Vienna Journal of East Asian Studies, Volume 3, eds. Rudiger Frank, Ingrid Getreuer-Kargl, Lukas Pokorny and Agnes Schick-Chen. Vienna: Praesens Verlag, 2012, pp. 165-192.

https://doi.org/10.2478/vjeas-2012-0006 


\section{Introduction}

Communicating exhibition contents is the essential task of a museum apart from collecting, conserving and researching. This is especially applicable to the category of history museums, which have not only historical responsibility but also a certain educational mandate for the general public to fulfil. These museums usually claim to introduce a neutral and truthful version of the past to their visitors. And while this demand seems widely accepted as today's standard of museum culture, the present paper will challenge this claim. Because when considering history, what exactly is truthful? And who is able to judge it to be so? Assuming the museum itself is to judge, one needs to remember that the museum staff is not bound to any judicial constrictions apart from keeping a basic sense of truth within the exhibition. Therefore, a history museum need not necessarily take a neutral position towards historic events, but may interpret them in a rather nationalistic or critical way. The positioning depends on the museum and its persons in charge, and may occur in very obvious and explicit ways as well as in discreet or even hidden forms. The reason for such different positions is that a universally accepted version of history does not exist. Moreover, memories of historic events are strongly affected by personal, cultural and ideological factors. Wars are an excellent example of this. After any military conflict the procedure of re-appraising happens in different ways between the prevailing and the defeated sides, with the conception of history of the victorious side emerging as the only tolerable version of the truth. It manifests itself in the slogan of 'history written by the victors', which is well known all around the globe today (Assmann 2006: 69). For defeated nations and their museums this procedure connotes difficulties in dealing with their own past and (re-)forming a collective national memory. In case of World War II, the defeated Axis powers, particularly the German and the Japanese empires, were marked as objects of undifferentiated evil after 1945. This mark meant a long and hard process of re-appraisal and rethinking, which affected all areas of social life and which in some cases has still not been completed up to the present. This paper focuses on the way museums have handled this kind of stigmatisation. In an international comparison, Japanese, German and Austrian museums will be examined to identify which factors are decisive for their ideological positioning and to what degree this position is consistent with the predominant conception of national history within the national society. For this purpose it is important to consider the relationship between politics and museums, as well as the relationship between museums and their visitors. After a brief review of previous re-appraisal efforts in Japan, Germany and Austria, a survey that students of the University of Vienna and students of Keiō University 慶応義塾大学 (keiō gijuku daigaku) in Tōkyō 東京 were invited to conduct themselves will provide specific data on the potential influence of museum exhibitions on their visitors, and thus help to underline the correlation between re-appraisal, remembrance and history mu- 
seums. Together with further information on the museums' legal and financial conditions, the main part of this paper will then analyse how four well-known museums of the former Axis powers are coming to terms with their countries' difficult history.

\section{The three nations and their museums}

Japan, Germany and Austria are well suited to an international comparison, since these three nations had many similarities before and during World War II, but showed different efforts in dealing with this time period after the defeat in 1945. In Germany, ever since the broadcast of the movie Holocaust in 1979, the nationwide efforts to re-appraise history have increased significantly. Under the title 'preservation of history', various fifty-year anniversary events were organised between 1983 and 1995, commemorating the victims of the Nazi regime. It was the beginning of the so-called 'culture of remembrance', which still today shapes all common war memories of society. For a long time Austria again tried to avoid critical discussions about the war by picturing itself as the first victim of Nazi Germany. By 1986, when the presidency of the former Wehrmacht soldier Kurt Waldheim caused a heavy international reverberation, the time for rethinking had come. Today the country is all the more ambitious about creating a common historical consciousness and of 'never forgetting' its own responsibility for the war and the war crimes committed. In Japan, similar initiatives have not taken place so far. The country's political importance in East Asia during the Cold War secured its support by the United States. Therefore a critical approach to Japanese war guilt did not seem helpful and was not actively pursued. Instead, a focus on technical modernisation blocked any critical vision on the past and promoted the tendency to look forward rather than back.

With the Yūshūkan 遊就館 ('House Where the Joy of Duty is Taught') in Tōkyō (YSK), the Heiwa Kinen Shiryōkan 平和記念資料館 (Peace Memorial Museum) in Hiroshima 広島 (HKS), the Deutsches Historisches Museum (German History Museum) in Berlin (DHM) and the Heeresgeschichtliches Museum (Museum of Military History) in Vienna (HGM), the development of four major history museums in these countries will now be taken as indicators of the national re-appraising of history. Analyses of the different exhibitions, together with an international comparison, will document the individual position of each institution as well as its political intention. The examination will show that although the events of World War II cannot be modified in any way, their reception within history museums remains subject to a constant process of development. Apart from a fundamental distinction between victors and defeated, even in nations with a similar historical fate the national culture of remembrance can vary considerably. Museums, as publicly operative interpreters of the past, play a decisive role within this national understanding of history. On the basis of these museums of the former Axis powers, it will become noticeable 
how museum perspectives on World War II can differ, and how these differences again may influence visitors' view of history. The example of Japan will further illustrate that even museums within the same country, depending on their ideological conception, may look at concrete historic events from a different point of view and therefore stand in contradiction to each other.

\section{The relevance of museums for the re-appraisal of history}

The correlation between re-appraisal, culture of remembrance and history museums can be clarified best by explaining two basic concepts of the collective memorythe communicative and the cultural memory. Communicative memory describes experiences, transmitted individually as well as orally, that individuals or groups of people have had in the past. It is a short-term memory that remains active for about two or three generations before it ceases to exist. Cultural memory, on the other hand, is an epoch-transcending, timeless construct, which relies on external media and institutions for an infinite and eternal distribution of memories. It includes architecture, monuments, traditions and rituals as well as the relicts on display in history museums. The decisive point is that remembrance within the cultural memory transforms itself into objective culture, which can or has to be acquired by learning (Cornelißen 2004: 13-14). This definition explains the relevance of history museums for the national policy of remembrance. As one factor in cultural memory, museums have the potential to co-form the memories of an entire society. They try to minimise the experience deficiency of their visitors and further assist in getting to know and understand history in an interesting and vivid way (Rauchensteiner 1997:58). Even if their significance compared to parental and academic education should not be overestimated, they still have a great responsibility in dealing objectively with the past.

To verify the actual potential for influencing of history museums, two surveys were conducted among one hundred politics students of Keiō University in Tōkyō and one hundred politics students of Vienna University in Austria. These surveys consisted of five central questions and were designed to help measure the popularity of national history museums, to clarify which exhibits left the greatest impressions and why, and also to demonstrate how visitors judge the general potential to influence of museums on their visitors. ${ }^{1}$ According to the evaluated results, more than 80 percent of the Austrian and Japanese students had already been to a history museum. With Hiroshima (41 percent) and Nagasaki 長崎 (23 percent) on top, the Japanese ranking was led by two remembrance institutions dealing with the events of the atomic bombs. Their high percentage is no surprise and can be explained by the

1 A translated version of the original survey can be found in the appendix. 
large number of school classes visiting these museums every year. As the only named war museum, the Yūshūkan received 7 percent of the votes, which is equal to fourth place. In Austria, due to its nationwide monopoly in historical matters, the HGM reached the top spot with a total of 29 percent, followed by the concentration camp of Mauthausen ${ }^{2}$ with 13 percent and the Jewish museums in Vienna and Berlin with 8 percent and 7 percent respectively. The results in both countries point to a clear dominance in numbers of peace-related or remembrance-related museums compared to more war- or military-related institutions. With 24 percent among the Japanese students and 18 percent of the Austrian students, the question on the most impressive exhibits of an history museum also conformed to this pattern. Thus, historical photos tended to leave the greatest impression within an exhibition-a result that emphasises the great importance of any visual constituent on display. Apart from photographic materials, there were significant theme-related differences in the vote as well, showing a focus on emotionalised objects like letters or diaries in Japan, while the Austrian students tended to memorise military-related objects like weapons, uniforms and tanks. The most decisive question in the survey was the last one, though, which examined the supposed potential of history museums to influence their visitors. Here the participants were asked to what degree they believed that museum exhibitions were able to influence the historical consciousness of their visitors, meaning to what extent they believed a museum could reinforce, modify or even disprove its visitors' previous view of history. It was possible to choose between the following four possibilities: 'strong influence', 'little influence', 'no influence', and 'I don't know'. Because of the minor efforts at re-appraisal in Japan, in the run-up it seemed more likely that Japanese students would believe in the strong influence of museum exhibitions. Austrian students, on the other hand, who have been regularly confronted with the 'dark' war years of their national history in various forms, such as media, school or parental education, were expected to take a more critical perspective towards the history shown or made within museums. Both presumptions proved to be wrong in the end, since the actual result showed an almost equal score between Austria and Japan. Fifty-nine percent of the Japanese students and even 61 percent of the Austrian students affirmed a strong museum influence, followed by 38 percent and 25 percent who believed in at least some possibilities to influence among history museums. The remaining percentage points were either allotted to 'I don't know' or to incompletely filled-out questionnaires.

2 The best-known former concentration camp on Austrian soil. 
Figure 1 The potential influence of history museums as a graph

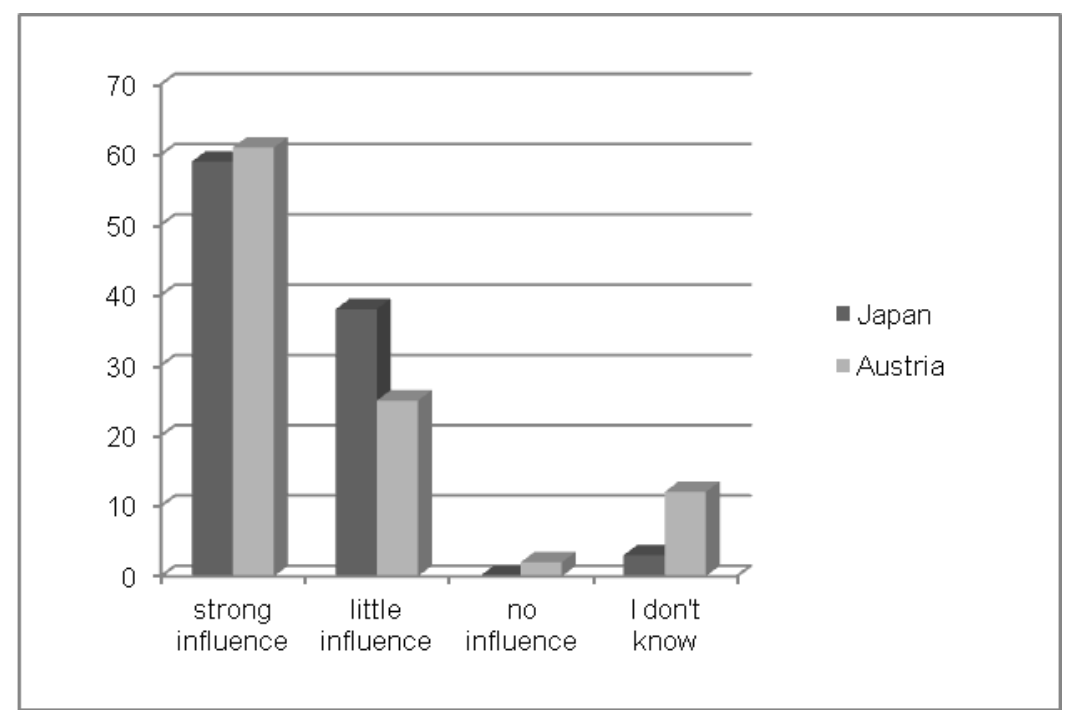

In summary, these results attest the influence of museums on the historical understanding of museum visitors. The high percentage of young people who have already been to a history museum demonstrates a wide spread of museum-related contents within society. In combination with almost two-thirds of the visitors who judged the influence of a museum to be strong, a convincing argument for the relevance and acceptance of history museums has been made. Similar results in both countries further bolster this impression, since they show the acceptance of museums by society, independent from the remaining culture of remembrance of the country. Also noticeable in the survey is an evident dominance of memorial institutions, which, in difference to war or military museums, raise the issue of victims and suffering in the first place. These museums happen to be the most visited museums in all three states, Japan, Germany and Austria. The most remarkable regional difference could be found in the question on the most impressive objects within an exhibition. Apart from the common naming of photos, Japanese students tended much more to personal items than their Austrian colleagues. A fact that underlines that in Japan it is more important for an exhibition to carry an emotional note, while in Austria the seeing and experiencing of historic events seem to be the most important aspects of a museum visit. 


\section{Legal and financial frameworks}

A further relevant factor in the museum comparison between Japan, Germany and Austria, is the legal framework for national museums. As Benedict Anderson has stated, museums and the imagination shaped by museums always have a political background (2005: 180). The actual influence of politics may vary, though, depending on a country's museum laws and the legal status of its institutions. One of the most effective ways of raising governmental influence is the allocation of financial support. Financial support creates a kind of dependency, which in consequence may increase governmental opportunities of control. However, this is only valid for officially recognised museums and not for private exhibitions. Furthermore, politics usually try not to interfere obviously in what concerns the content of a museum's exhibition. That is why the connection between politics and museums cannot be generalised, but has to be examined for each country individually, as the case arises.

While Germany and Austria use similar legal structures, the legal system in Japan has created its own, individual rules. The Japanese Museum Law was enacted in 1951 and still exists in its original form up to the present. It is the fourth highest level of jurisdiction after the national constitution and is controlled by the Ministry of Education (Kaneko 2001: 19). In contrast to Europe, Japanese museums need not necessarily observe the law to ensure their existence. Governmental interference in internal museum issues can be easily avoided by simply not registering the museum as an official institution. In Japan, a non-official status is not illegal and does not have any severe consequences for the museums affected, apart from the loss of possible tax privileges. Some museums even welcome non-official status in order to silence the otherwise demanding voice of the ministry. The resulting lack of governmental control allows everybody in Japan the opportunity to open their own museum and to show inside whatever they like. That is why in 2002, Japan recorded the large figure of 3,091 history museums, with only 292 of them officially registered by the state. ${ }^{3}$ In Germany and Austria, a similar development would be impossible, since both countries have strict museum laws to regulate daily museum business and also to enforce bans on forbidden or very controversial contents within an exhibition. Museums that deal with sensitive topics like World War II and its consequences are in particular often subject to close supervision. In addition to legal control by the state, close co-operation also exists with ICOM - the International Council of Museums. ICOM is a non-governmental organisation that works for the sustainment and illustration of every kind of cultural heritage. For that reason ICOM has issued the 'Code of Ethics', the first standardised guideline for museums around the world. This code is designed to help define a common international standard for

3 Data from an interview with Kaneko Atsushi 金子淳, professor at the University of Shizuoka 静岡大学 (shizuoka daigaku) and an expert on Japanese museum law, 26 November 2007. 
the visualisation of history and of the culture of remembrance. Compliance with this guideline is voluntary and can be decided individually by each museum from the 112 member states. While German and Austrian museums seem keen to fulfil the international demands to a great degree, Japanese museums have so far barely taken notice of ICOM's existence.

The analyses of the museum policies show analogies to other efforts for reappraising history in these three countries. While Germany and Austria are eager to establish a certain historical picture in the minds of their people, Japan acts passively and hesitantly in this respect. One might claim that German and Austrian museums adopted a version of history imposed upon them by the victors of World War II, while Japanese museums have, rather, retained their ideological and traditional spirit and therefore mirror the variety of autonomous Japanese views more truthfully. The majority of Japanese history museums enjoy an absolute freedom of action in the organisation of their exhibitions. Some even of the biggest and best-known institutions are privately managed and financed, and are therefore free from governmental control. Both of the Japanese museums in this comparative study, the YSK in Tōkyō and the HKS in Hiroshima, belong to this category. The YSK is subordinate only to the nearby Yasukuni Shrine 靖國神社 (yasukuni jinja), which is further responsible for the entire museum budget of 2 billion yen a year (equal to 12.26 million euro) (Hosokawa 2007: 18). And since the museum employees are also mainly recruited from the shrine, close ties between these two institutions are inevitable. This guarantees that the museum will follow the shrine's orders and will introduce a revisionist picture of history to visitors. The HKS for its part is administered by the Peace Culture Foundation $(\mathrm{PCF})$, an organisation that is responsible for a large number of remembrance institutions inside and outside Japan. The PCF branch in Hiroshima owns a budget of 1.8 billion yen a year (equal to 11 million euro), a considerable part of which is used directly for the HKS. ${ }^{4}$ This financial dependency makes the relationship between the HKS and the PCF similar to the one between the YSK and the Yasukuni Shrine, with the only difference that the PCF enforces a rather liberal and left-wing version of history. This dependency on non-governmental institutions is one obvious difference between the Japanese museums and their European counterparts in this comparison. The DHM as well as the HGM are officially registered institutes, both under the control of the state and its museum law. Nonetheless, the DHM receives a large part of its budget through subventions. From a total budget of 19.84 million euro, no less than 17.11 million euro come from the 'Beauftragten für Kultur und Medien' (Federal Government Commissioner for Culture and the Media), an agency of the federal government that supports cultural and media achievements in Germany. In comparison, the HGM in Austria has a yearly budget of only 3 million euro and is therefore the least resourced of all four museums in this study 
(Zillinger 2004: 111). It is also the only museum that is subordinate to the Austrian Ministry of Defence and for that reason has a direct connection to the national military forces.

Despite these structural and financial differences a comparison remains valid because of the two main criteria for selecting the museums. First, the national and international reputation of the museums was considered, measured by the number of publications about them, the number of existing websites, and not least by the number of mentions in the survey conducted. Second, the yearly number of visitors that would guarantee a similar societal influence and importance of the particular museums was examined. Here the HKS dominates the ranking with approximately 1.1 million visitors a year. In second place comes the DHM with about 400,000, followed by the YSK with 320,000 visitors in $2007 .^{5}$ The HGM is at the bottom of the list, but at the same time is the museum that recently made the greatest progress. Within the past five years, the number of visitors almost tripled from 63,000 in 2005 to currently 172,000 in 2010 (HGM-Info 2012).

\section{The Yūshūkan}

First opened in 1882, the YSK presents itself as Japan's oldest museum. It is located in the central district of Chiyoda 千代田区 (chiyoda-ku) in Tōkyō, inside the garden complex of the famous Yasukuni Shrine. ${ }^{6}$ Freely translated the name Yūshūkan means 'house where the joy of duty is taught' and gives a first impression of the museum's ideological position. To describe World War II, the YSK uses the term Dai Tōa Sensō 大東覀戦争, which stands for 'Great East Asian War' and is considered a rather nationalistic term. It was officially used by the Japanese from 1941, until forbidden by the American occupying power in 1945. Today a critical view is taken of this expression and it is not as widespread as alternative terms like Dai Niji Sekai Taisen 第二次世界大戦 (World War II) or Taiheiyō Sensō 太平洋戦争 (Pacific War). According to a survey conducted by the daily newspaper Asahi Shimbun 朝日新聞 in 2006, a clear majority of 56 percent preferred the neutral Dai Niji Sekai Taisen over Dai Tōa Sensō, which received only 10 percent of the mentions (Asahi Shimbun 2006: 229). Either way, World War II is without doubt the most essential section of the museum's permanent exhibition. With five big halls in the basement, not less than half of the entire floor space is dedicated to the war events

5 Numbers for the YSK from an interview with Yamamoto Shingo 山本眞吾, director of exhibitions at the museum, 31 October 2007.

6 The Yasukuni Shrine was founded in 1869 and is dedicated to men and women who lost their lives while serving Japan and the Japanese imperial army. Some of the 2,466,000 spirits currently enshrined and worshipped belong to convicted wartime criminals, causing this otherwise spiritual site to be known also as a place of controversy and recurring international disputes. 
between 1939 and 1945. Within that space, history gets told from a very Japanesecentred perspective. Apart from one marginal explanation of the political ties and military strengths of the major European powers at the entrance to the floor, no further attention is given to any international events in the conflict. Instead, the YSK expends much effort in first informing its visitors of the great Japanese will to avoid war with the United States. Many photos and texts are displayed to document the various diplomatic meetings between the Japanese ambassador in Washington, Nomura Kichisaburō 野村吉三郎, the then Japanese foreign minister, Matsuoka Yōsuke 松岡洋右, and the American ambassador in Tōkyō, Cordell Hull, to settle political differences peacefully. The ultimate failure and termination of these talks on 26 November 1941 is then blamed exclusively on the 'insufficient American willingness to compromise'. On the basis of the so-called Hull note, the Americans demanded a complete withdrawal of all Japanese forces from their recently gained territories in China and Indochina. This was, according to the museum's information panels, a completely unrealistic demand that could only be understood as an ultimatum. At the same time, the previously aggressive Japanese policy of expansion is justified by the growing need for raw materials. For the YSK, any kind of military retreat would have seriously threatened the future supply of the empire. Left with no other options, on 7 December 1941 the imperial forces of Japan started the war against the United States by a surprise attack on the American Pacific Fleet at the island of Pearl Harbour. The exhibition on the following years of war is divided into five different sections:

- Offensive campaigns: 8 December 1941 to May 1942

- Turning point: June 1942 to September 1943

- Defensive campaigns: September 1943 to 15 August 1945

- Measures to defend Japanese territory: February 1945 to 15 August 1945

- End of war and rebuilding of Japan

The structure of these sections is generally always the same. Up to three showcases are dedicated to each of the major historic battles and are predominantly filled with personal belongings of fallen Japanese soldiers. Besides basic information panels, statistics are also on display, introducing the approximate number of soldiers and war machines engaged in combat. Detailed maps of the Pacific theatre additionally enable the visitor to see and understand the tactics and movements of the Japanese forces and their enemies. In this way, the visitor is put into the role of a general who is being informed about every relevant action taken on the battlefield. Despite this accurate and chronological documentation of the war, all events that might possibly harm the reputation of the Japanese imperial forces are intentionally omitted. For example, violence against the civilian populations of occupied territories receives no attention at any time. Neither are there reports on the 'comfort women', forced la- 
bourers, internment camps or the notorious unit 731, which conducted various medical experiments on living subjects and was responsible for the death of thousands of people between 1932 and 1945. Even the well-known 'massacre of Nánjīng' 南京大 虛殺 (nankin daigyakusatsu) is only termed an 'incident' 事件 (jiken) involving 'confusing battles' with the defending Chinese forces. Hints on the high number of casualties or the war crimes that may have occurred during the conquest of the former Chinese capital are missing completely. The obvious military setbacks of the final years are explained insufficiently as well and avoid the mention of any kind of failures or defeats. Regardless of actual battle results, the soldiers in charge still get praised for their great commitment and brave spirit against a superior enemy. The depiction of the war ends with the 'heroic battle' for Okinawa between 1 April and 23 June 1945. Subsequent events, including the nuclear attacks on Hiroshima and Nagasaki, find no place in the YSK. Instead, the last three rooms of the exhibition are reserved for remembrance of the Japanese war dead. Within this section more than 3,000 soldiers are individually portrayed with name, photos, military ranks and places of death. This honour is destined only for those soldiers who are also enshrined at the nearby Yasukuni Shrine.

\section{Perception of the exhibition}

The substance of the YSK consists primarily of emotionalisation instead of information. The main function of the museum is to worship the heroic souls of fallen Japanese soldiers. For the best possible implementation of this philosophy, the YSK presents a patriotically transfigured version of history within its exhibition rooms. It is a version of history that can be best described as incomplete and in some cases even as one-sided and biased. Disagreeable or critical details that could cast a shadow on the deeds of the Japanese imperial army get ignored as far as possible. Obvious examples would be the total neglect of the colonial period in Korea or the superficial mention of the massacre of Nánjīng 南京. In addition, the display of war events from the European theatre is left out for the best possible nationalistic staging of the Japanese forces. The main focus of the YSK is to create an emotional connection between the visitors of today and the soldiers from the past. Thus, many of the war relics on display are personal items rather than weapons and war machines, creating a more personal base of identification for visitors. The profiles of more than 3,000 fallen soldiers cause a further personification that transforms formerly anonymous victims into actual existences. Death gets a face and is noticeable in all its tragic coverage. This kind of visualisation causes compassion and concern in visitors - a reason why any critical approach to historical issues gets drastically constricted. The tight connection between general war history and the tragic fate of the individual makes every critic of the exhibition automatically a critic of the fallen 
soldiers - something that Japanese people, imbued with a culturally rooted, deep respect for the dead, particularly want to avoid. In such a way the YSK can create enough clearance and coverage to continue spreading its nationalistic perspective within Japan. Still, the price to pay for its subjective, one-sided version of history is high. The YSK is not registered as an official museum and has no further cooperation with other history museums inside or outside of Japan. As a consequence, it is difficult to realise special exhibitions or institute any other changes in the permanent display rooms, since the museum always depends respectively on itself and on the goodwill of the Yasukuni Shrine. The shrine is the only institution to support the museum, but in return demands a voice in all important internal museum affairs.

\section{The Heiwa Kinen Shiryōkan}

After some early temporary exhibitions in the late 1940s, it was the "Hiroshima Peace Memorial City Construction Law' of 1949 that determined the transformation of the central area of Nakajima 中島 into a permanent memorial park. As the park's centrepiece, a comprehensive history museum was planned in the years up to 1951 . Four and a half years of construction later, the main building of the HKS was officially opened on 24 August 1955. Unsurprisingly, the HKS sets its focus primarily on 6 August 1945, the day when the first atomic bomb was dropped on the city of Hiroshima. Around 90 percent of the entire exhibition area is dedicated to this theme. Nonetheless, today's museum also left some space to introduce Japan's path into war, and specific wartime events that may have led to the nuclear attack. Thus it is intended that visitors should learn that the tragedy did not happen without reason and that Japan itself was responsible for starting the war. As part of the complete reorganisation of the Eastern Hall in 1994, a new section was established to document the history of the war up to August 1945. Within this section approximately twenty information boards were put up, explaining the historic importance of Hiroshima from the Meiji restoration until 1945. Particular emphasis is placed on the importance of war-related issues. The city is depicted as a traditional place for heavy industry and as an alternative headquarters for the Japanese government. The museum further uses the history of the fifth division, a military unit stationed in Hiroshima, to point out other relevant war events outside the city borders. The fifth division was engaged in numerous campaigns against China, Korea, Russia and the United States and also participated in the battle for Nánjīng. Its actions are depicted as an example of the generally aggressive Japanese expansionism and its negative side-effects. In contrast to the YSK, much attention is paid to crimes against humanity. One central concern of the museum is to strengthen visitors' awareness of how much pain and suffering war can cause. With that purpose, parts of the exhibition were designed to equally provoke and shock their visitors. The information panel 
about the 'massacre of Nánjīng', for instance, contains remarkable sentences such as: 'Hiroshima's residents celebrated with a lantern parade. In Nanking, however, Chinese people were being slaughtered by the Japanese army.,

Figure 2 Japanese text on the 'massacre of Nánjīng' inside the HKS

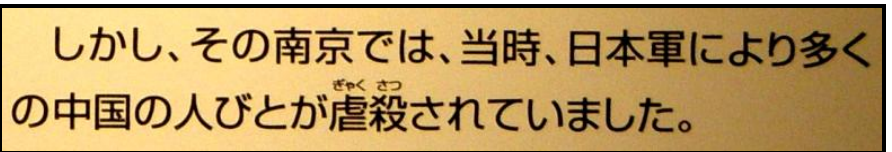

The exact wording of the text of this panel was at the origin of many discussions and had to be adapted several times. In its current version, the hard term 'slaughtered' especially remains subject to ongoing protests from Japanese visitors. This is just one example illustrating how relentlessly the HKS tries to depict the war period and how it even dares to condemn the deeds of Japanese soldiers. Such critical understanding of history is rather unusual in Japan. According to Steven Leeper, head of the PCF and the one in charge of the exhibition's content, the distinct respect for the past makes it almost impossible to criticise publicly former actions of the elderly and dead in Japan. The resentment and resistance would be enormous, and not only among the relatives of the perpetrators. That is why Leeper, an American and the first non-Japanese head of the PCF, found it so difficult to realise fully his critical intentions for the permanent exhibition. ${ }^{8}$ Another example of the polarising concept of the museum was the controversial display of a diorama. It contained two wax figures, a mother and her child, who stumbled through the ruins of the devastated city just moments after the detonation. Their clothes were ripped and their skin was so heavily burned that it hung in shreds from their limbs. The presentation of this scene was so realistic and shocking that it had to be deactivated and replaced by a slightly more moderate version. ${ }^{9}$

\section{Perception of the exhibition}

In the same way as the YSK, the HKS in Hiroshima also prefers an emotionalised exhibition to reach the minds of its visitors. Again there are tragic fates of individuals on display to show the great suffering of wartime. But unlike the exhibition in the museum in Tōkyō, the exhibition in Hiroshima is dedicated not to the fallen

7 The Japanese text is: 'Shikashi, sono Nankin dewa, tōji, Nihon gun ni yori ōku no Chūgoku no hito bito ga gyakusatsu sarete imashita.'

8 Leeper originally tried to create an even more provocative exhibition by installing significantly more panels with critical texts and shocking images. The lack of acceptance among Japanese, however, allowed only some aspects of his vision actually to be realised.

9 The information in this paragraph comes from an interview with Steven Leeper, 3 December 2007. 
soldiers, but to the remembrance of the thousands of civilian victims. Special focus is laid on the depiction of the children of Hiroshima. With the help of deeply moving texts, the last moments in the lives of these young people is told, while in nearby showcases, objects such as burned school uniforms or a devastated three-wheeler generate an oppressive feeling. The focus on the youngest victims of the bomb is no coincidence and can be statistically proven by checking the register of the official museum guide. The register shows that, for instance, only one-quarter of all objects on display at the section on 'material witnesses' 遺品は語る (ihin ha kataru) belonged to persons older than fifteen on the day of the detonation. The remaining 75 percent are relics that all belonged to children who lost their lives because of the bomb. Among the total number of 19,000 objects in the museum's possession, those directly or indirectly connected primarily to children found their way into the permanent exhibition. Thus the shock potential of the exhibition is increased to the maximum degree. The HKS uses the consternation of its visitors about the senseless deaths of innocent children to reach the greatest possible level of emotionalisation and to spread its messages for peace in an optimal way. However, this perception is only true for the second part of the tour, the original museum exhibition. By taking a look at the museum as a whole, explicit changes and even contradictions between the different concepts of the Eastern Hall and the main building come to the surface. While the original exhibition primarily tries to induce compassion for the victims, the new entrance hall aims to list feasible reasons why the United States dropped the bomb on Hiroshima. Within this section, the museum's ambition is to illustrate the strategies and cruelties of Japanese warfare. Most of the information panels about the history of Hiroshima are used to point out the great relevance of the city during World War II. As a temporary seat of government for the emperor, the base of the fifth division, home to various military facilities and a remarkable naval port, the museum wants to make clear that the city was not selected as a potential target without reason. It is a version of history that helps to legitimate the deeds of the American forces. As a result, even some significant historical facts remain unaddressed. No text panel in the exhibition explains that all the previously mentioned military facilities were located outside the city limits or that, despite its alleged military importance, Hiroshima had never before been selected as a target for American bombings. Furthermore, President Truman's statement admitting that he expected about 100,000 casualties should the United States drop the bomb on Hiroshima, receives no space in the museum's considerations. The museum even impedes the logic of its own arguments at some points. In a specific section named 'Reasons for dropping the bomb on Japan', ${ }^{10}$ located at the end of the entrance hall, the HKS ignores all the factors mentioned previously from the panels. Instead it lists the geographical location, the weather conditions on the morning of the attack, and the fact that there were 
no American soldiers in POW camps ${ }^{11}$ nearby, as decisive reasons for the nuclear bombing of Hiroshima.

\section{Deutsches Historisches Museum}

The DHM exhibition is domiciled inside the historic building of the Zeughaus- the former Prussian arsenal. The Zeughaus is located on Berlin's grand boulevard 'Unter den Linden' and was first opened to the public in 1830, to present relics from the wars of liberation between 1813 and 1815 (Koschnick 2006: 13). Ever since, it has undergone numerous changes and transformations, depending on the conditions of Germany's variable political framework. In today's form, it was officially (re-) opened on 2 June 2006. Within the museum's current exhibition, World War II is embedded in the section about Nazi rule over Germany between 1933 and 1945 . These twelve years under the leadership of Adolf Hitler are represented in two large rooms which cover about one-sixth of the whole exhibition area. Considering that the DHM deals with 2,000 years of German history, it is legitimate to speak of a strong emphasis on the events before and during World War II. A basic division is made between the years 1933-1939 and 1939-1945. Within these two periods there is a total of 66 subcategories which are all chronologically arranged and differentiated by their respective topics. The first period provides insights into the National Socialist ideology as well as into all relevant developments up to the outbreak of war. Architecture, art, motorway construction or the Olympic Games are covered to the same extent as politics, exclusion, persecution and terror against minorities. The second period starts with September 1939 and is structured as follows:

- 1939-1941: The first years

- 1941-1943: Radicalisation of the war

- 1943-1945: Total war and genocide

The depiction of these six years is composed of two essential factors. Apart from information on military operations and the different theatres of war, it strives mainly for a critical confrontation with German war crimes. In contrast with the Japanese museums examined in this study, the DHM makes no clear distinction between military and humanitarian aspects of the war. The last part of most of the information panels is saved for the portrayal of events apart from military operations. In addition, one separate section of the exhibition is dedicated wholly to the National Socialist genocide during the war. Here, concentration camps, death marches and deportations find particular mention. Though all minorities are covered, special emphasis is put

11 Prisoner of War (POW) camp, a place where captured enemy soldiers are held during wartime. 
on crimes against the Jewish population within the empire and the occupied territories. Great attention is also shown to the German resistance during wartime. In a separate showcase with seventeen compartments, some of the best-known German resistance fighters, such as Claus Schenk Graf von Stauffenberg, receive special recognition by having their photos and letters put on display or by even being honoured with detailed bronze busts. While the exhibition does its best to illustrate each and every facet of the war, the information on the final year 1945 seems a bit superficial. The chronological depiction jumps from a short mention of D-Day and the advance of the allied troops in France and Italy that followed it, directly to the 'Last contingent of the Volkssturm, ${ }^{12}$ and the battle for Berlin, leaving out the last German offensive in the Ardennes or the Russian recaptures in Eastern Europe. This section thus appears incomplete. This is even more obvious when comparison is made with the previous detailed information on the Eastern Front and the extensive documentation of German war crimes. One of the last subsections of the exhibition focuses on the first months after the German capitulation. Under the title 'Liberated and defeated', ${ }^{13}$ the perception of the end of the war among the German population is discussed. One panel of text presents the interesting line that 'differently from today, hardly anyone could feel liberated, who had witnessed the war on the German side'.

\section{Perception of the exhibition}

With a few exceptions, World War II gets depicted in as extensive and detailed a fashion as is possible within the available space. Through various subsections, each complemented by appropriate historical relics, the museum communicates the most comprehensive impression of the events between 1939 and 1945. The visitor gets good insights into all the chronological happenings of the war, an indication of how accurately the museum staff have handled the composition and content of their exhibition. At the same time, the publicised motto of the museum to 'examine German history in a European context' makes the positioning of the DHM difficult. Despite great efforts at objectivity and neutrality, the focus on the idea of European unification and on an international audience makes it very likely that the DHM will use a rather self-critical perspective towards German history. It is a perspective that can provoke a distorted view of facts and therefore cause a biased perception among its visitors. The entire conception for the six years of the war is characterised by German humbleness and remorse. For that reason the museum tries not to show any content that might produce negative reactions from foreign countries. Topics that

12 The German text is: 'Das letzte Aufgebot des Volkssturms'.

13 The German title is: 'Befreite und Besiegte'. 
could potentially be seen as a distraction from historic German mistakes or war crimes get blocked out in a way similar to the suppressing of the misdeeds of Japanese soldiers in the YSK. World War II is presented solely as German guilt, to be planted in the visitor's mind in an appropriate way. Major parts of the exhibition appear like a late apology to the international community of states and further demonstrate the willingness of the German people to deal relentlessly with the 'dark years' of their history. The section on National Socialist rule thus suffers from a recurrent imbalance in its presentation. While German war crimes represent a larger portion of the exhibition's content, misdeeds from the opposite side get largely concealed. A good example is the invasion of the Soviet Red Army. When the Russian forces marched into Germany in 1945, various crimes like rape, murder and looting were committed against the civilian population, with the majority of German people left at the mercy of their invaders. In the DHM, these months of terror receive only small attention and only get mentioned casually in one general passage of text about the final defeat. The history museum in Berlin-Karlshorst, which enjoys close cooperation with the DHM and which also gets mentioned in its museum guide, offers its visitors a much more critical perspective on the same time period. Corporately administered by Germans and Russians, it deals with war crimes from both sides in an equal way and therefore communicates a sufficiently realistic version of history compared to the DHM. This example clarifies the problematic situation of many German museums, particularly when it comes to criticising other parties participating in World War II. Even though there were crimes against humanity on all sides of this war, the confrontation with the own guilt always appears to come to the forefront in Germany. Only the museum in Karlshorst can be an exception because all its contents have to be approved by the Russian administration as well. The DHM, lacking this kind of legitimation by the 'other side', prefers to introduce a predominantly self-critical exhibition to educate its visitors and to please the expectations of the international community as well.

\section{Heeresgeschichtliches Museum}

Construction work on the HGM lasted from 1850 until 1856. The museum may therefore pride itself on being the first museum building in Austria to be planned and erected as such. Officially opened by Emperor Franz Joseph I in 1869, it suffered uneven development over the following decades as it tried to survive two world wars. Its popularity peaked in the $1960 \mathrm{~s}$, when the museum counted an average of 400,000 visitors a year. At that time the HGM was listed as the second most successful military museum in all Europe (Schubert and Schubert 2002: 86). Today, the section on World War II is part of an exhibition hall with the title 'Republic and Dictatorship_Austria from 1918 until 1945'. Together with the events of the inter- 
war period, not more than one-twelfth of the entire exhibition area is dedicated to this topic: a rather small part for a museum that usually has tried to cover every battle of the monarchy as extensively as possible. Hence, the visitor cannot help but feel that, contrary to the YSK and the DHM, World War II does not belong to the museum's preferred historic events. The fact that the Austrian nation ceased to exist and entered war only as an appendage of the German empire is in strong contradiction to the patriotic, glamorous display rooms from before and impinges inevitably on the conception of the exhibition. The inherent tragedy of events now makes it impossible to praise iconic military leaders or to view the battles in a heroically transfigured way. Almost overnight the more or less glorious history of the Austrian monarchy turned into the cruel history of Germany. The resulting ideological conflict cannot be denied and manifests itself in the scant relevance this war has inside the HGM. While World War I has been the central part of the exhibition at all times, World War II was not even integrated into the exhibition until public consciousness drastically changed in the late 1980s. Then suddenly, the previous section on the naval history of the monarchy got transferred to a side wing of the building, while newly placed showcases were filled with World War II relics from the museum depot. Today the one exhibition room is divided into two sides. The left side is covered with showcases and also offers space for a video area, where a film about Austria during the years 1941 and 1945 is shown. Inside the showcases, all kinds of warrelated topics are displayed. The range goes from the cult of the leader to armament and equipment of the Wehrmacht, then through to resistance, concentration camps and capitulation. Missing divisions in the particular cases make it difficult to orientate oneself and let the arrangement of the objects seem chaotic. The right side of the room is mainly reserved for large exhibits like cannons, cars or other heavy units. It is also the place for an art installation by Professor Curt Stenvert to remember death and pain in the battle of Stalingrad. Within three separate showcases, numerous surreal cruelties are visualised to shock visitors and to illustrate the senselessness of war. The biggest object in the exhibition, a reconnaissance aircraft from the type Fi 156 C-Trop (Fieseler Storch), is fixed to the ceiling, from where it shapes the image of the entire room. All in all, a first look at the number and quality of the exhibits lets the museum's confrontation with World War II seem extensive and intense. This impression is relativised, though, as soon as the panels of text are read. The written explanations are very limited and offer visitors only the most basic information. One remarkable detail of the museum's texts is the repeated mention of Austria and Austrian soldiers within the German Wehrmacht. Strictly speaking, this is an incorrect formulation, since there was no such country for the duration of the war. 


\section{Perception of the exhibition}

The HGM's exhibition defines itself mainly through the objects on display and tries to avoid any critical approach to delicate topics of World War II. It is the only museum in this study that does not inform its visitors explicitly with accompanying texts, but only 'confronts' them with the topic by displaying the objects. Partially impressive relics allow the visitors to feel and experience the past, but missing explanations keep them from getting to know and understand it better. The few information panels lack detailed explanations and therefore raise more questions than they can answer. This gets even more obvious when comparing the exhibition about World War II with sections about previous wars. Visitors to the HGM, for instance, have the opportunity to learn about every single individual year of World War I. The showcases have clear divisions and contain detailed information about all the European theatres of war. The result is a comprehensible, easy-to-follow overview of the historic events between 1914 and 1918. So why was this successful scheme not implemented for World War II as well? How is it possible to explain this completely different approach to both world wars? The answer to these questions may be found in the distinct patriotism of the HGM. It is the only museum in Austria that is administered by the ministry of defence and therefore has a certain responsibility to represent the military history of Austria and its soldiers in a somewhat glorious way. Despite numerous defeats and disappointments under the Habsburg rule, the battles of earlier times were still well qualified in this matter. Even in the worst military losses and setbacks, a kind of competency could always be depicted, even if only through focusing on famous historic characters like Prince Eugen, Maria Theresia or Field Marshal Radetzky. It was not until the defeat of 1918 and the following 'mutilation' of Austria into a marginal midland without access to the sea that this romanticisation of Austria's past became a serious problem. The HGM's texts thus express a certain bitterness about the sudden collapse of the monarchy. At one point in a discussion of post-war politics, a text panel literally says:

\footnotetext{
Austria's boundaries were set by the victors. Neither nationality nor history influenced this process - utility was the only decisive element. Austria was what had been left over in the bankruptcy proceedings of the Habsburg Empire. [...] Italy took South Tyrol. Czechoslovakia took whatever it deemed desirable.
}

Having already severe difficulties in sustaining the patriotic depiction of history after 1918, this undertaking became nearly impossible for the HGM in 1938. The annexation of Austria by the German empire and the resulting loss of national sovereignty were incompatible with the previously patriotic concepts of the museum's exhibition. As a consequence, the HGM first decided to boycott World War II as a whole within its display rooms. When the changed historical consciousness of society rendered this scheme impossible, the museum appears to have switched to an- 
other kind of boycott-a boycott of information. The section about World War II has meanwhile been part of the HGM since the 1980s, but still has surprisingly few panels of text to offer. There is so little text and explanation that the greatest war in human history could not be introduced in a more basic way than it is in the HGM. The international comparison with Germany and Japan additionally supports this assumption. While the other three museums in this study may have their individual version of history as well, they at least try to communicate this history to their visitors. The HGM instead acts more like a military museum and prefers to show the weapons, uniforms and machines of World War II without commentary. This approach may generate a nice optic, but does not automatically qualify for a good exhibition.

\section{Conclusion}

Japan, Germany and Austria have followed an individual philosophy of re-appraisal and have therefore created a different basis for their national museum landscape. In Japan, a critical debate about the Japanese role in World War II has still not taken place. For too long the war has been told only on the basis of personal stories, avoiding the formation of a homogeneous historical consciousness within society, but preserving varied perceptions of the past. The only exception in this matter is the common perspective on the atomic bombings of Hiroshima and Nagasaki. The permanent exhibitions of the YSK and HKS both confirm this assumption. Both museums introduce an emotionalised interpretation of World War II, which should not be misunderstood as the standardised opinion of the Japanese public. Great ideological discrepancies about one and the same historic event underline much more the different points of view among Japanese people. The YSK primarily addresses its content to the visitors of the nearby Yasukuni Shrine, who belong mostly to the nationalconservative political camp. The biggest groups of visitors are businessmen, veterans and the relatives of veterans. ${ }^{14}$ In recent years the museum has also realised the importance of youth and raised its efforts to attract more scholars and students. Beside some initiatives in schools and the installation of appropriate information panels for children, the museum has founded its own youth group named Asanagi 朝凪..$^{15}$ The group numbers about 300 members, who all work voluntarily at the museum and the shrine (Asahi Shimbun 2006: 201). For the YSK the greatest concern is to keep the memory of victorious battles alive and to honour the fallen Japanese sol-

14 Data from an interview with Yamamoto Shingo, director of exhibitions at the YSK, 31 October 2007.

15 The name 'Asanagi', meaning 'morning calm', originates from a patriotic song for Emperor Shōwa 昭和天 皇 and is intended to symbolise peace. 
diers within the exhibition rooms. A patriotic, transfigured and partially even incorrect version of history is to convince the visitors of the rightness of World War II.

In contrast, the peace museum at Hiroshima vies for the attention of the other spectrum of society. That includes all those people who have a critical attitude towards war and who primarily want to commemorate its civilian victims. In the beginning, public interest in Hiroshima as the place of the first nuclear bombing was not high enough. That is why, starting from the 1980s, the museum launched various political initiatives to engage more actively for world peace. The new engagement made it necessary for the museum to restructure its exhibition and move it from a focus solely critical of America to an equally self-critical perspective. The current result of this restructuring is a split, contradictory exhibition which is never really able to differentiate between the victim and the perpetrator role of Japan during World War II. Furthermore the museum is eager to establish a direct connection between the atomic bomb and peace. It convoys the impression that without nuclear weapons wars would no longer be going on in the world. Similarly to the request for a world without nuclear bombs, such visions of the museum seem like pure utopia and are one reason why the HKS is frequently criticised and why it cannot gain noticeable importance in political affairs (Fujiwara 2001: 137). Just like the YSK, the HKS has also acknowledged the great importance of young people and tries to address this issue. Special agreements even exist between the museum and nationwide elementary and middle schools. Every year numerous school buses bring pupils and teachers from all over Japan to the museum, where they are taught about the tragic events of August 1945. The percentage of children among the general number of visitors is accordingly high and accounts for about 30 to 40 percent each year. ${ }^{16}$ The result of the survey conducted as part of this study, where Hiroshima turned out to be the most visited museum among the Japanese students, additionally confirms these official numbers.

The great relevance of history museums in the shaping of the historical consciousness of young people can similarly be seen in Germany and Austria. In a point of difference from Japan, though, in these two countries the examination of World War II is also socially prevalent, so that museums are just one source of information and remembrance, together with academic, parental and media education. Nonetheless, 61 percent of the Austrian students in the survey described the museum influence as 'strong'. This result can be explained by the small ideological spectrum of the local history museums. As an outcome of a widely homogeneous historical consciousness of World War II, intensively promoted by German and Austrian politics over the last decades, museums in these countries are very likely to present only thematically well-adapted exhibitions. As a consequence, museums for peace and remembrance in particular enjoy great popularity nowadays. The DHM, for instance, 
has to compete against plenty of other history museums in and around the city of Berlin. In the German capital, much attention is paid to the delicate topic of World War II and its remembrance. Potential visitors have the possibility of choosing between institutions like the official holocaust memorial, the house at Checkpoint Charlie, the Jewish museum, the exhibition on resistance during the National Socialist rule, the German-Russian museum in Karlshorst, the concentration camp of Sachsenhausen and many more places. Apart from particular thematic emphases, the general message of these museums does not differ and can be placed in the same alignment as the exhibition of the DHM. They all have their focus on the crimes of the Nazi regime and its soldiers and condemn these deeds as offensive. The fierce competition among museums due to ideological uniformity explains the modest number of visitors at the $\mathrm{DHM}^{17}$ and further demonstrates the consequences of an intense German confrontation with its own war guilt in recent years. Meanwhile, German people appear to have invariably accepted their problematic role in the past and lost much of their previous national pride because of the long-lasting, difficult process of re-appraisal. Emotionalised school lessons about the war seem further to cause German youth to grow up with an acquired guilt complex that will hardly allow a second perspective on the past and that gets additional support from the version of history presented in German history museums (Braun 2012)

Austria is on a similar path to establish a common understanding of World War II, but still lags a few steps behind its northern neighbour. The remaining difficulties can be shown on the basis of the content of the exhibition at the HGM. Even though the culture of remembrance has developed significantly throughout the past ten to fifteen years, the myth of Austria being the 'first victim of Nazi Germany' is still anchored persistently in public perception. The HGM picks up on that thesis and supports the antiquated picture of an innocent and defenceless Austria as a plaything of German world politics. The exhibition in its current form therefore stands in opposition to the version of history officially propagated by the state. A contradiction like that only gets tolerated because of two characteristics or privileges the HGM enjoys. First, the HGM is the only Austrian museum administered by the ministry of defence and is therefore more strongly shaped by military influences than by political ones. And second, as the only existing museum of general and military history in Austria, the HGM still has a monopoly position that prevents it from getting compared to or criticised by any other historical institutions within the country. That its interpretation of World War II still remains a thorn in the flesh of official politics becomes obvious in the fact that the Austrian government is very committed to establishing a central 'Haus der Geschichte' (house of history) in the near future. The

17 In 2002, the Berlin Senate's department for education, science and research ranked the museums in Berlin by their number of visitors. Within this ranking, despite its central location, large budget and historic importance, the DHM reached only 14th place (Pressemitteilungen des Landes Berlin 2003). 
plan is to build a new museum where Austrian history shall be reappraised in a European context - a slogan that resembles the DHM's in a very obvious way. Meanwhile, other proposals have been made to unify the 'Haus der Geschichte' directly with the HGM, within one and the same building. In that way the new museum would have enough objects on display right from the start, and the politics could further increase its influence on the content and conception of the exhibition. The final decision has still not been made, although the matter has been under intense consideration for years.

Such movements within the museum landscape prove that even though the history of World War II will not change any further, its re-appraisal remains a steady process that from time to time requires restructuring measures of museum contents as well. Each museum in this comparative study has undergone more or less prominent changes within the past two decades. The DHM had its great restructuring after the reunification of Germany in 1990 and after the restoration of the building in 2005/06. In Hiroshima it was in the year 1994, when a newly opened entrance area of the HKS introduced a rather self-critical version of the responsibility for the Japanese war. The HGM in Vienna did not integrate World War II as a whole into its permanent exhibition until the 1980s and is still searching for an adequate positioning vis-à-vis the eight years under Nazi German rule. Last but not least, the YSK has also undergone some modernisation measures and tries to build on its pre-war popularity since the official re-opening in 2002. For that purpose the nationalist content of the exhibition was boosted once more, while simultaneously the focus was shifted to the remembrance of the fallen Japanese soldiers and much money and effort was put into various campaigns to attract young people.

While the museums in Berlin and Tōkyō have already found their stance, the renewal process in Hiroshima and Vienna is not yet finalised. According to the current situation and personal statements from Steven Leeper, head of the PCF, the peace museum in Hiroshima is likely to restructure its presentation once again. It is planned to take a step back and shift the focus from self-critical enlightenment efforts back to the sheer remembrance of the atomic bomb victims. The HGM, however, will have to take a step in the opposite direction in the foreseeable futureaway from forcing a victim's role for Austria towards a more self-critical discussion of the country's responsibility in World War II. Sooner or later it will, together with a new house of history, adapt its exhibition to the current concept and content of the DHM in Berlin, which will mean looking at national history merely in a European dimension and avoiding any kind of nationalism on display.

By comparison, Japan does not have to face such international guidelines. Nobody would try to display Japanese history in an Asian context. The isolated location of the island state contributes rather to a self-centred and independent historical standpoint, which prevents Japan from dealing voluntarily with accusations from former wartime enemies. One interesting aspect about this philosophy is the still 
existing differentiation between Asian nations and the United States. While Japan began to accept the United States as the dominant world power right after the war had ended, it still looks down on its Asian neighbours today. It is a phenomenon that is also visible in both Japanese museums in this study. The museum in Hiroshima uses questionable argumentations to legitimise the dropping of the atomic bomb in order to avoid any new conflicts with America. In addition, it is the first time in history that an American, in the person of Steven Leeper, is the head of the PCF and therefore able to shape the permanent exhibition of the HKS from an American perspective. And even the nationalistic YSK holds back with its criticism of America, while it has no problem with attacking China, Russia and Korea openly in its exhibition. In 2006, for instance, the museum changed a controversial text on the former United States president Franklin D. Roosevelt after the United States had intervened successfully. Similar protests from the Chinese or Korean side, however, received no consideration. Examples like these demonstrate the relevance of current political relations for the ideology of history museums - in Asia as well as in Europe. The only difference is that Japanese museums are free to choose their preferred position towards national history, while in Austria and Germany the historical institutions are exposed to direct control by the state.

Either way, the four museums in this study tell us a lot about the predominating view of history in their countries and societies. In Germany and Austria there is a current trend to establish peace and memorial museums which will ideally depict national history in a broader European context and further fulfil an educational function as well. Nationalism is experienced as negative and is prevented occasionally by politics. In Japan, however, politics do not interfere with the ideals of the museum landscape and even tolerate a proliferation of non-registered historical institutions. The result is a wide range of historical viewpoints that in only a few cases are willing to offer a critical perspective of the Japanese past. As regards content, great importance is attached to emotions and remembrance among descendants. This remembrance, however, only concerns the Japanese deceased and puts war victims of other nationalities to one side.

But since the re-appraisal of history is a never-ending process, the evaluation of different museum landscapes can only be a snapshot at best. It remains to be seen how the historical consciousness of the people and the history museums will further develop and change in future. This present study of four of the best-known history museums of the former Axis powers, therefore, should be understood only as a basis for further discussion and research. 


\section{APPENDIX}

Questions used for the survey in Austria and Japan

1) Gender: male / female

2) Age: __ years

3) Place of residence

4) Have you ever been to a history museum?

$$
\text { yes / no }
$$

5) If you answered question 4) with 'yes'- which museum(s) have you been to? (name and city)

6) What detail of the exhibition left the biggest impression on you?

7) Do you know of any history museum in Japan (for Austrian students) / in Austria or Germany (for Japanese students)?

$$
\text { yes / no }
$$

8) If you answered question 7) with 'yes' - which museum do you know?

9) Do you think the content of a museum's exhibition can influence the historical consciousness of its visitors?
1) yes - certainly
2) a little
3) no - not at all
4) I don't know 


\section{REFERENCES}

Anderson, Benedict. Die Erfindung der Nation. Zur Karriere eines folgenreichen Konzepts [first published in 1983 as Imagined Communities: Reflections on the Origin and Spread of Nationalism]. Frankfurt and New York: Campus, 2005

Asahi Shimbun 朝日新聞編. Sensō-sekinintotsuitō-rekishitomukiau 1 戦争責任と追悼 - 歴史と 向き合う 1 [War Guilt and Remembrance - In the Mirror of History 1]. Tōkyō: Asahi Shimbun, 2006, p. 201

Assmann, Aleida. Der lange Schatten der Vergangenheit: Erinnerungskultur und Geschichtspolitik. München: Beck, 2006

Braun, Maria. "Warum sich die Deutschen selbst nicht mögen”, Welt Online, http://www.welt.de/politik/deutschland/article13813483/Warum-sich-die-Deutschen-selbstnicht-moegen.html, accessed May 2012

Cornelißen, Christoph. "Nationale Erinnerungskulturen seit 1945 im Vergleich." In Erinnerungskulturen. Deutschland, Italien und Japan seit 1945, edited by Christoph Cornelißen and Lutz Klinkhammer. Frankfurt am Main: Fischer Taschenbuch, 2004, pp. 9-2

Fujiwara, Kiichi 藤原帰一. Sensōo kioku suru - Hiroshima, Horokōsuto to genzai 戦争を記憶す る - 広島、ホロコーストと現在 [To Remember the War - Hiroshima, Holocaust and the Present]. Tōkyō: Kōdansha, 2001

HGM-Info. "Erfolg trotz Krise", http://bundesheergewerkschaft.wordpress.com/vorteile/kulturelles/hgm-info/, accessed May 2012

Hosokawa, Kōtarō 細川幸太郎. Sensō-tenji no imi. Hakubutsukan no kokusai-hikaku 戦争展示の 意味. 博物館の国際比較 [The Relevance of War Exhibitions. An International Comparison of Museums]. M.A. thesis, Tōkyō Daigaku, 2007

Kaneko, Atsushi 金子淳. Hakubutsukan no seijigaku 博物館の政治学 [The Politics of Museums]. Tōkyō: Seikyū, 2001

Koschnick, Leonore. Deutsches Historisches Museum Berlin. Berlin, Munich a.o.: Prestel, 2006

Pressemitteilungen des Landes Berlin. "Besucherzahlen der Berliner Museen 2002", http://www.berlin.de/landespressestelle/archiv/2003/11/17/16617/, accessed April 2011

Rauchensteiner, Manfried. "Das Heeresgeschichtliche Museum in Wien." In Der Krieg und seine Museen, edited by Hans-Martin Hinz. Frankfurt am Main: Campus, 1997, pp. 56-72

Schubert, Peter, and Wolfgang Schubert. Das Wiener Arsenal. Klosterneuburg: Mayer und Comp., 2002

Zillinger, Karl. "Hofrat Dr. Manfried Rauchensteiner, Direktor des Heeresgeschichtlichen Museums, im Gespräch mit Mag. Karl Zillinger, Oberleutnant der Reserve.” In Aktuell, 1, 2004, pp. 109-114 


\section{INTERVIEWS}

Kaneko, Atsushi 金子淳. Interviewed by author, Shizuoka, 26 November 2007

Leeper, Steven. Interviewed by author, Hiroshima, 3 December 2007

Yamamoto, Shingo 山本眞吾. Interviewed by author, Tōkyō, 31 October 2007 


\section{GLOSSARY}

\begin{tabular}{|c|c|c|}
\hline Asahi Shimbun & 朝日新聞 & Japanese newspaper \\
\hline Asanagi & 朝戌 & morning calm \\
\hline Chiyoda-ku & 千代田区 & central district in Tōkyō \\
\hline dai niji sekai taisen & 第二次世界大戦 & world war II \\
\hline dai tōa sensō & 大東亜戦争 & great East Asian war \\
\hline Heiwa kinen shiryōkan & 平和記念資料館 & Peace Memorial Museum \\
\hline Hiroshima & 広島 & city on the island of Honshū \\
\hline ihin ha kataru & 遺品は語る & material witness \\
\hline jiken & 事件 & incident \\
\hline Kaneko Atsushi & 金子淳 & $\begin{array}{l}\text { Professor at the University of Shizuoka and } \\
\text { expert on Japanese museum law }\end{array}$ \\
\hline Keiō gijuku daigaku & 慶応義塾大学 & Keiō University, Tōkyō \\
\hline Nagasaki & 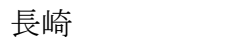 & city on the island of Kyūshū \\
\hline Nakajima & 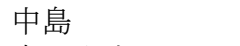 & park area in the centre of Hiroshima \\
\hline Nankin daigyakusatsu & 南京大虐殺 & 'Massacre of Nánjīng' \\
\hline Nánjīng & 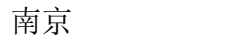 & major city in eastern China \\
\hline Nomura Kichisaburō & 野村吉三郎 & former Japanese ambassador to Washington \\
\hline Matsuoka Yōsuke & 松岡洋右 & former Japanese foreign minister \\
\hline Shizuoka daigaku & 静岡大学 & University of Shizuoka \\
\hline Shōwa-tennō & 昭和天皇 & $\begin{array}{l}\text { Emperor Hirohito (1901-1989), who reigned } \\
\text { between } 1926 \text { and } 1989\end{array}$ \\
\hline taiheiyō sensō & 太平洋戦争 & pacific war \\
\hline Tōkyō & 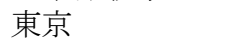 & capital of Japan \\
\hline Yamamoto Shingo & 山本眞吾 & director of exhibitions at the Yūshūkan \\
\hline Yasukuni jinja & 靖國神社 & 'shrine of the peaceful country' \\
\hline Yūshūkan & 遊就館 & 'house where the joy of duty is taught' \\
\hline
\end{tabular}

